\title{
Antibacterial activity of selected medicinal plants and its economic importance of Khyber agency, Pakistan
}

Muhammad Arif ${ }^{1}$, Kashif Ali ${ }^{2}$, Muhammad Shuaib ${ }^{3 *}$, Umar Zeb ${ }^{4}$, Tariq Aslam $^{5}$, Zara Urooj ${ }^{5}$, Muzammil Shah ${ }^{6}$, Firasat Hussain ${ }^{7}$, Saddam Hussain $^{8}$, Sajjad Ahmed ${ }^{8}$, Syed Sadaqat Shah ${ }^{5}$, Ikramullah Khan ${ }^{9}$ and Fida Hussain ${ }^{10}$

1. Department of Microbiology, Abasyn University, Peshawar-Pakistan

2. Institute of Ecology and Geobotany, Yunnan University, No.2. North Cuihu road, Kunming, Yunnan, 650091, PR-China

3. School of Ecology and Environmental Science, Yunnan University, No.2. North Cuihu road, Kunming, Yunnan, 650091, PR-China

4. Key Laboratory of Resources Biology and Biotechnology in Western China, Ministry of Education, College of Life Science, Northwest University, Xian 710069-China

5. Key Laboratory of Vegetation Ecology, Ministry of Education, Institute of Grass Science, North East Normal University, Changchun, 130024-China

6. Department of Biological Sciences, King Abdulaziz University, Jeddah-21589, Saudi Arabia.

7. Department of Microbiology, University of Swabi-Pakistan

8. Key Laboratory of Molecular Epigenetics of Ministry of Education, School of Life Science, Northeast Normal University, Jilin-China

9. Department of Botany, Abdul Wali Khan University, Mardan-Pakistan

10. School of Resources, Environmental and Chemical Engineering Nanchang University, Nanchang Jiangxi-China *Corresponding author's email: zeyadz44@yahoo.com

\section{Citation}

Muhammad Arif, Kashif Ali, Muhammad Shuaib, Umar Zeb, Tariq Aslam, Zara Urooj, Muzammil Shah, Firasat Hussain, Saddam Hussain, Sajjad Ahmed, Syed Sadaqat Shah, Ikramullah Khan and Fida Hussain.Antibacterial activity of selected medicinal plants and its economic importance of Khyber agency, Pakistan. Pure and Applied Biology Vol. 7, Issue 2, pp745-753. http://dx.doi.org/10.19045/bspab.2018.70093

\begin{tabular}{llll}
\hline \hline Received: 05/04/2018 & Revised: 22/06/2018 & Accepted: 25/06/2018 & Online First: 25/06/2018 \\
\hline \hline
\end{tabular}

\section{Abstract}

The current study is focused to explore the economic importance of selected medicinal plants of Khyber agency, Pakistan. A total of 58 medicinal plants species was collected, out of which 47 species were economically used and 5 medicinal species were checked for their antibacterial activity. The results of antibacterial activity revealed that these plants have good antibacterial potential which needs further phytochemically, biological and pharmaceutical investigations.

Keywords: Antibacterial activity; Medicinal species; Economic value; Khyber Agency; Pakistan

Introduction

Plants are the excellence of nature and these plants have incredible restorative and monetary significance all through the world. All day by day human essential and rich prerequisites like encouraging, garments, haven, nursing, and chasing are satisfied by plants. As plants are wellsprings of pharmaceuticals, they have shaped the reason for creative and conventional frameworks 
and consistently giving humankind new cures. In the past couple of years, the enthusiasm for customary pharmaceutical has exceptionally expanded. This teach is picking up the logical reason for its suitable application [1]. The vegetation of Pakistan because of it's assorted climatic and soil conditions and numerous natural locales are exceptionally rich in restorative plants. As per a general review of Pakistan, around 6000 types of blossoming plants have existed; out of 6000, around 400 to 600 are therapeutically imperative species [2-4].

Numerous plants can possibly be utilized as a characteristic cure against ailments [5]. Homegrown pharmaceuticals have been the fundamental wellspring of essential social insurance in all countries. The plants as medication are utilized as a part of the distinctive arrangement of drugs, for example, Ayurveda, Allopathy, Unani, Homeopathy and even in different frameworks. The historical backdrop of plants to be used as medications is a huge number of years old [6].

Around $80 \%$ of the total populace is as yet subject to the conventional solution. From old circumstances, plants have been a rich wellspring of viable and safe solutions. Because of their sheltered, viable and modest nature, indigenous cures are mainstream among individuals. We may call homegrown solution as the medication in which plantbased details are utilized to mitigate ailments. It is otherwise called organic pharmaceutical or phytomedicine [7,8]. The term phytotherapy has been, be that as it may, presented as of late as a more precise equivalent word of natural or plant drug. In the mid-twentiethcentury, natural pharmaceuticals were wellsprings of the prime medicinal services framework, before the disclosure of anti-toxins or analgesics. With the approach of an allopathic arrangement of prescription, homegrown pharmaceutical step by step lost its fame among individuals, which depends on the quick helpful activities of engineered drugs [8].

In the eighteenth century, a society therapeutic specialist Reverend Edward Stone used to treat a fever by using the bark of white willow (Salix alba) with a similar severe have an aftertaste like Cinchona. The rule in charge of controlling fever in willow bark was salicin, a simple of salicylic corrosive. Other firmly related characteristic mixes were progressively found and found to assuage fever, torment, swelling, gout, rheumatic fever, and joint pain. A medication reserpine secluded from foundations of Rauvolfia serpentinae was utilized as a part of the treatment of hypertension, snakebite and dysfunctional behavior. Cases of other profitable medications from characteristic sources incorporate sedatives and pilocarpine utilized for glaucoma, dry-mouth disorder while vincristine and vinblastine got from Catharanthus roseus recommended for pediatric leukemia and Hodgkin's sickness, individually, which demonstrates that therapeutic plants have the important wellspring of restorative specialists since time immemorial and keep on playing an overwhelming part in essential human services [9].

Keeping in view the importance of medicinal plants, some medicinal plants were selected from Khyber agency to expose the economic benefits and to explore the medicinal potential of these plants. The current paper will enlist the important plant in the local area, economical plants in the local area and antimicrobial activity of five species.

\section{Materials and methods Collection of plant}

The fresh flower and leaves of selected plants, viz., Justiciaadhatoda, Datura stramonium, Boerhavia procumbens, Chenopodium murle and Euphorbiahelioscopia free from pathogenic diseasewere collected from the research area. 
These plants were washed 4 times thoroughly with distilled water.

\section{Preparation of extract}

Washed dried leaves and flower of selected plant $J$. adhatoda, $D$. stramonium, $B$. procumbens, $C$. murle and E. helioscopia were first dried in shade for 3 days. These plants were placed in an oven at $35^{\circ} \mathrm{C}$ and then converted into powder with mortar and pestle. 100 grams of each respective plant parts and $200 \mathrm{ml}$ of methanol were placed ina mortar and it was ground thoroughly with the pestle. The extract of methanol was kept at room temperature for $33 \mathrm{~h}$. The prepared extract was filtered using filter paper and then dried at temperature of $40^{\circ} \mathrm{C}$ for methanol removal to obtain the dense extract and then they were kept in sterile bottles under refrigerated conditions until use.

\section{Antibacterial activity}

In this biological evaluation, a total of six bacterial species were chosen to be used. The bacterial species used were classified as Gram-negative bacteria such as Escherichia coli, Pseudomonas fluorescens and Xanthomonas axonopodis and gram-positive such as Bacillus subtilis and Staphylococcus aureus. All these organisms were sustained on agar slant at $4^{\circ} \mathrm{C}$ and the slant was allowed to activate at a temperature of $37^{\circ} \mathrm{C}$ for one day on nutrient agar (NA) before any screening was carried out. The organisms were kept in Müller-Hinton agar (MHA) in the refrigerator at $4{ }^{\circ} \mathrm{C}$ prior to subculture. Antibacterial testing was conceded out on the already developed agar well diffusion method to study the effectiveness of the extracts of selected medicinal plants. Broth media was primed and the test organisms were moved to the broth media from agar plate and were grown-up at $37^{\circ} \mathrm{C}$ for one day. After 24 h, $25 \mathrm{ml}$ of MHA were discharged into each Petri plate and cooled in sterile condition. The fresh culture was primed from day old culture, after solidification of MHA in the plate; $0.6 \mathrm{ml}$ of afresh culture of test organism was emptied onto MHA. Wells of 6 $\mathrm{mm}$ diameter were dug into the medium by using sterile borer and $20 \mathrm{mg}$ of the extracts of selected medicinal plants were used against each organism. DMSO and standard antibiotic (Streptomycin sulphate) were mixed into other wells. The plates were kept in pasteurized inoculation chambers for 60 min to facilitate diffusion of the antimicrobial agent into the medium. The plates were then incubated at $37^{\circ} \mathrm{C}$ for one day and the diameters of the zone of inhibition of microbial progression were measured in millimeters [10].

\section{Economic value}

Khyber Agency is rich in varieties of flora and has a diverse habitat. The flora is economically very important to the local people, who use it in caring for various diseases. Herbalists make traditional medicines which are the most common way available of caring for the most frequent diseases. The regional plant dealers sell the plants to local markets and export them to the International market as a way of earning money. The economic data collected from the local market sellers and analyzed it.

\section{Results and discussion}

In Khyber Agency, 58 plants were collected in the current survey from 2015 to 2016. These medicinal plants are sold locally as well as internationally in markets and support the economy of the local people. Only 11 medicinal plants are currently trading in national and international markets while the rest of the medicinal plants were used and sold locally. The local people of the area use indigenous medicinal flora for the treatment of many diseases and also sell many of them in the local market for earning their livelihood $[3,11,12]$. The use of the whole plant of the herb was the most frequent practice, which is present in the market for medicinal purpose. Different parts of plants are first dried and then converted into powder form which is then sold to markets (Table 1). 
Plants like Cuscuta reflexa L., Foeniculm vulgare, Medicago sativa L., Morus alba L., Morus indica L., Ficus palmata Forssk. and Ficus carica L. is the plants which are frequently sold in the market for their medicinal value in the current survey, which is also cited by Sher and Hassan [13] in their research article in Northern part of Pakistan. In the current study, some plants were also reported, which are used for fuel purposes besides their medicinal values, viz., Dodonea viscose L., Zizphus jujba Mill. and Zizphus nummularia (Burn.f.). Ali et al. [14] also reported that these plants are sources of medicine and fuelwood which endorse our research work. The native families of the area are farmers, collection and selling of medicinal plants are their supplementary source of income. Earlier researchers like [3, 13-15] also conducted similar research studies and their research is in analogy with current research. Khyber agency contains some important medicinal flora for various disorders. The present survey documented some important medicinal flora for their international export like Ammi visnaga, Artemisia Vulgaris, B. procumbens L., and Berberis lycium, Helianthus annus L., Diospyrus lotus, Juglan sregia, Mentha arvensis L., Mentha logifolia and $F$. vulgare to many other countries for medicinal purposes (Table 2). Khan and Khan, [16] also reported the same plants in the Mountain Region of Abbottabad and also documented the aforesaid plants export to different countries of the world. Other research scientists [16-18] also reported the export of medicinal plant to national and international markets which is mentioned in the current research study.

\section{Antimicrobial activity of plants}

In the present research study, the antimicrobial activity of some selected plants was tested which showed a significant effect against different bacterial strains (Table 3). B. procumbens, Chenopodium murale and $E$. helioscopia were selected for antimicrobial activity. The leaves and flower extract of the aforementioned plants were tested against five bacterial species, viz., B. subtilis, E. coli, $P$. fluorescens, $S$. aureus and $X$. axonopodis. The extract of each plant showed a significant effect against all the selected five different species of bacteria. The extract of $J$. adhatoda, both the flower and leaves showed significant result against all selected species of bacteria, even higher than the standard antibiotic. J. adhatoda flower and leaves extract showed significant antimicrobial activity against the $B$. subtilis $(18 \pm 0.76$ and $17 \pm 0.10$ respectively); the flower extract expressed an antimicrobial activity of $13 \pm 0.16$ against $E$. coli, while leaves extract 12.01; more also, the flower and leaf extracts exhibited antimicrobial activities of $12 \pm 0.23$ and $11 \pm 0.03$ against $P$. fluorescens, respectively. The present report showed the similarity with $[19,20]$. The extract of $D$. stramonium showed significant antimicrobial activity against each bacterial species except $E$. coli to which the extract was not much effective. The leaves extract of $B$. procumbens exhibited significantly high antimicrobial activity but the flower extract was not much effective as compared to the leaves extract. The extract of $C$. morale was quite effective against $S$. aureus species while its antimicrobial activity against other species of bacteria was low compared to the other plants. The E. helioscopia leaves extract has a high potential for all bacterial species except $X$. axonopodis to which its antimicrobial effect was significantly low [21, 22]. 
Table 1. Marketing medicinal plants of Khyber agency

\begin{tabular}{|c|c|c|c|c|c|c|}
\hline $\begin{array}{l}\text { S. } \\
\text { No. }\end{array}$ & Plant name & Local name & Family & Part use & $\begin{array}{c}\text { Collection } \\
\text { method }\end{array}$ & References \\
\hline 1 & $\begin{array}{l}\text { Ajugabracteosa wall. } \\
\text { ex. Benth }\end{array}$ & Gotty & Lamiaceae & Whole plant & - & [3] \\
\hline 2 & Ammi visnaga & Kaaga & Mimosaceae & Bark & Plucking & [3] \\
\hline 3 & Artemissia vulgaris & Tarkha & Mimosaceae & Bark & Digging & [3] \\
\hline 4 & Bauhinia variegata $\mathrm{L}$. & Kachnar & - & Whole plant & Cutting & \\
\hline 5 & $\begin{array}{c}\text { Boerhaviaprocumbens } \\
\text { L. }\end{array}$ & - & Nyctagianceae & Whole plant & Cutting & \\
\hline 6 & Berberis lycium & Goray & - & Latex & $\begin{array}{c}\text { Digging, } \\
\text { cutting }\end{array}$ & [3] \\
\hline 7 & $\begin{array}{l}\text { Chenopodium botryst } \\
\text { L. }\end{array}$ & Surmahy & Chenopodiaceae & Whole plant & Picking & \\
\hline 8 & $\begin{array}{l}\text { Chenopodium murale } \\
\text { L. }\end{array}$ & $\begin{array}{l}\text { Toorsur } \\
\text { Makhay }\end{array}$ & Chenopodiaceae & Whole plant & Picking & \\
\hline 9 & Convolvulus arvensisL. & Prewata & Convolvulaceae & $\begin{array}{l}\text { Roots and } \\
\text { Leaves }\end{array}$ & Picking & \\
\hline 10 & Corindrum sativum $\mathrm{L}$. & Daria & Apiaceae & $\begin{array}{l}\text { Leaves and } \\
\text { Seeds }\end{array}$ & Picking & [3] \\
\hline 11 & CuscutareflexaL. & Pachy & Cuscutaceae & Whole plant & Cutting & \\
\hline 12 & $\begin{array}{c}\text { Carthamus oxycantha } \\
\text { M. bieb }\end{array}$ & - & Asteraceae & Seed & Cutting & \\
\hline 13 & Cyperus rotundus & Dela & Cyperaceae & Whole plant & Digging & \\
\hline 14 & - & Tor Amlok & Ebenaceae & Wood/Fruit & Cutting & \\
\hline 15 & Cucurbita pepo L. & Kado & Cucurbitaceae & Fruit & Cutting & \\
\hline 16 & Calendula officinalis L. & Ziar gul & Asteraceae & Shoot/ flower & Plucking & \\
\hline 17 & Diospyrus lotus $\mathrm{L}$. & SoorAmlok & Ebenaceae & Wood/fruit & $\begin{array}{l}\text { Cutting, } \\
\text { Plucking }\end{array}$ & [3] \\
\hline 18 & Datura stramonium L. & Datura & Solanaceae & Seed/ leaves & Plucking & \\
\hline 19 & Helianthus annus L. & Nwar parst & Compositae & Whole plant & Plucking & \\
\hline 20 & $\begin{array}{l}\text { Hederanepalensis K. } \\
\text { Koch }\end{array}$ & Perwathe & Araliaceae & Fruit leave & Plucking & \\
\hline 21 & Dodonea viscose (L.) & Khamba & Sapindaceae & Whole plant & Plucking & \\
\hline 22 & Diospyrus lotus & - & - & Leaves & Plucking & [3] \\
\hline 23 & $\begin{array}{c}\text { Euphorbia helioscopia } \\
\text { Mewski }\end{array}$ & Gandabotay & Euphorbiaceae & Whole plant & Plucking & \\
\hline 24 & Euphorbia prostrate L. & Gandabotay & Euphorbiaceae & Whole plant & Plucking & \\
\hline 25 & $\begin{array}{l}\text { Eryobotrya japonica } \\
\text { (Thunb) Lindle }\end{array}$ & Lokat & Rosaceae & Wood/ fruit & $\begin{array}{l}\text { Cutting, } \\
\text { plucking }\end{array}$ & \\
\hline 26 & Fumaria indica L. & Nelay & Fumariaceae & Whole plant & Digging & \\
\hline 27 & Ficus palmata Forssk. & Enzar & Moraceae & Whole plant & Plucking & \\
\hline 28 & Ficus carica $\mathrm{L}$. & Baghe inzar & Moraceae & Whole plant & Plucking & \\
\hline 29 & Ficus religiosa Roxb. & Peepal & Moraceae & Wood & Cutting & \\
\hline 30 & $\begin{array}{l}\text { Foeniculm vulgare } \\
\text { Mill. }\end{array}$ & Kaga & Apiaceae & $\begin{array}{c}\text { Seed and } \\
\text { leaves }\end{array}$ & Plucking & [3] \\
\hline 31 & Jusitcia adhatoda L. & Baikaar & Acanthaceae & Leave, root & Digging & \\
\hline 32 & Jasminum humile L. & Chamba & Oleaceae & Root, leaves & Plucking & \\
\hline 33 & Juglans regia & Guz & - & Root, leaves & $\begin{array}{l}\text { Plucking, } \\
\text { cutting }\end{array}$ & \\
\hline 34 & $\begin{array}{l}\text { Luffa cylindrical (L.) } \\
\text { Room }\end{array}$ & Torai & Cucurbetaceae & Whole plant & $\begin{array}{l}\text { Cutting, } \\
\text { plucking }\end{array}$ & \\
\hline 35 & Lactuca serriola L. & Shenaygul & Asteraceae & Leaves & Plucking & \\
\hline 36 & Melia azedarach L. & Bakyane & Meliacae & Whole plant & Cutting & \\
\hline
\end{tabular}


Arif et al.

\begin{tabular}{|c|c|c|c|c|c|}
\hline 37 & Menthaarvensis L. & Podina & Lamiaceae & Leaves & $\begin{array}{l}\text { Cutting, } \\
\text { plucking }\end{array}$ \\
\hline 38 & $\begin{array}{c}\text { Menthalogifolia }(\mathrm{L}) \\
\text { Huds }\end{array}$ & Wenaly & Lamiaceae & Leaves & Plucking \\
\hline 39 & Morus alba L. & Speen tooth & Moraceae & Fruit & $\begin{array}{c}\text { Plucking, } \\
\text { cutting }\end{array}$ \\
\hline 40 & Morus indica $\mathrm{L}$. & Toor Tooth & Moraceae & Fruit & $\begin{array}{c}\text { Plucking, } \\
\text { cutting }\end{array}$ \\
\hline 41 & Medicago sativa $\mathrm{L}$. & Peshtary & Papillionaceae & Whole plant & Picking \\
\hline 42 & Malva neglecta Wallr & Panderak & Malvaceae & Whole plant & Picking \\
\hline 43 & Narcissus tazzeta L. & Gul-e- nargis & Amaryllidaceae & Flower & Plucking \\
\hline 44 & $\begin{array}{c}\text { Nostortium officinale } \\
\text { R.Br. }\end{array}$ & Tarmeera & Brassicaceae & Seed & Plucking \\
\hline 45 & Zizphus jujba Mill. & Bari & Rhamnaceae & Fruit & Plucking \\
\hline 46 & $\begin{array}{l}\text { Zizphus nummularia } \\
\text { (Burn.f.) Wight }\end{array}$ & Karkara & Rhamnaceae & Fruit & Plucking \\
\hline 47 & Oxalis carniculataL. & Gulbusho & Oxalidaceae & Whole plant & Plucking \\
\hline
\end{tabular}

Note. The other plant species and collection method is first reported in the present survey. No literature was found for collection of the plants or plants part in country before same is also in export 
Table 2. List of plants traded in National and International Markets from Khyber agency, Pakistan

\begin{tabular}{|c|c|c|c|c|c|c|c|c|c|}
\hline S. No. & Plant names & Local name & Family & $\begin{array}{l}\text { Parts used } \\
\text { and export }\end{array}$ & Export locally & $\begin{array}{c}\text { Export to } \\
\text { international } \\
\text { market }\end{array}$ & $\begin{array}{c}\text { Price } \\
\text { per kg }\end{array}$ & $\begin{array}{c}\text { Amount } \\
\text { transport per } \\
\text { season }\end{array}$ & References \\
\hline 1 & Ammi visnaga & Kaga & Mimosaceae & Bark & Peshawar, Lahore & - & 180 & 10,00 & $\ldots \ldots$ \\
\hline 2 & Artemissia vulgaris & - & Mimosaceae & Bark & Lahore & - & 100 & 50,000 & $\ldots \ldots$ \\
\hline 3 & Berberis lyceum & $\begin{array}{l}\text { Koray, } \\
\text { zairlargay }\end{array}$ & Berberidaceae & Latex & $\begin{array}{c}\text { Peshawar, } \\
\text { Lahore, Karachi }\end{array}$ & $\begin{array}{c}\text { India, } \\
\text { Germany, } \\
\text { Iran, Europe }\end{array}$ & 300 & 100,000 & \\
\hline 4 & $\begin{array}{c}\text { Boerhavia } \\
\text { procumbens } \mathrm{L} .\end{array}$ & - & Nyctagianceae & Whole plant & - & - & - & 30,000 &.. \\
\hline 5 & Diospyrus lotus & Perseman & Ebenaceae & Leaves & Peshawar, Lahore & - & 40 & 100,000 & [18] \\
\hline 6 & Diospyrus kaki & Tooramlook & Ebenaceae & Leaves & Peshawar, Lahore & - & 40 & 100,000 & [18] \\
\hline 7 & Foeniculmvulgare & Kaga & Umbelliferae & Seeds & $\begin{array}{c}\text { Peshawar, } \\
\text { Karachi, Lahore }\end{array}$ & India, Europe & 400 & 10,000 & {$[18]$} \\
\hline 8 & Helianthus annus L. & Nwarparst & Compositae & Whole plant & $\begin{array}{c}\text { Lahore, Karachi, } \\
\text { Faisalabad } \\
\end{array}$ & $\begin{array}{c}\text { Belgium, } \\
\text { France, India }\end{array}$ & 100 & 20,000 & {$[18]$} \\
\hline 9 & Juglans regia & Guzz & Juglandaceae & Root/Leaves & Peshawar, Lahore & $\begin{array}{l}\text { Saudi Arabia, } \\
\text { Dubai, China }\end{array}$ & 1000 & $1,80,000$ & {$[18]$} \\
\hline 10 & Mentha arvensis L. & Podina & Lamiaceae & Leaves & Peshawar, Lahore & $\begin{array}{c}\text { China, } \\
\text { Afghanistan }\end{array}$ & 100 & 100,000 & {$[18]$} \\
\hline 11 & $\begin{array}{c}\text { Mentha logifolia (L) } \\
\text { Huds }\end{array}$ & Wenaly & Lamiaceae & Leaves & Peshawar, Lahore & $\begin{array}{c}\text { China, Saudi } \\
\text { Arabia } \\
\end{array}$ & 100 & 80,000 & [18] \\
\hline
\end{tabular}

Table 3. Antibacterial activity of some medicinal plants, methanol extract $(100 \mu \mathrm{g} / \mathrm{ml})$ and antibiotic $(80 \mu \mathrm{g} / \mathrm{ml})$ against bacterial species tested by the disc diffusion assay

\begin{tabular}{|c|c|c|c|c|c|c|c|c|c|c|c|}
\hline \multirow[t]{2}{*}{ Bacterial strain } & \multicolumn{2}{|c|}{ Justicia adhatoda } & \multicolumn{2}{|c|}{ Datura stramonium } & \multicolumn{2}{|c|}{ Boerhaviaprocumbens } & \multicolumn{2}{|c|}{ Chenopodium murle } & \multicolumn{2}{|c|}{$\begin{array}{c}\text { Euhorbia } \\
\text { helioscopia }\end{array}$} & \multirow{2}{*}{$\begin{array}{l}\text { Streptomycin } \\
\text { sulphate }\end{array}$} \\
\hline & Flower & Leaves & Flower & Leaves & Flower & leaves & Flower & Leaves & Flower & Leaves & \\
\hline Bacillus subtilis & $18 \pm 0.76$ & $17 \pm 0.10$ & $16 \pm 0.06$ & $15 \pm 0.27$ & $14 \pm 0.26$ & $13 \pm 0.16$ & $12 \pm 0.18$ & $11 \pm 0.27$ & $10 \pm 0.21$ & $16 \pm 0.36$ & $15 \pm 0.16$ \\
\hline Escherichia coli & $13 \pm 0.16$ & $12 \pm 0.11$ & $11 \pm 0.10$ & $10 \pm 0.10$ & $7 \pm 0.70$ & $11 \pm 0.02$ & $13 \pm 0.21$ & $14 \pm 0.26$ & $13 \pm 0.03$ & $16 \pm 0.03$ & $17 \pm 0.18$ \\
\hline $\begin{array}{l}\text { Pseudomonas } \\
\text { fluorescens }\end{array}$ & $12 \pm 0.23$ & $11 \pm 0.03$ & $12 \pm 1.21$ & $16 \pm 1.90$ & $10 \pm 0.43$ & $12 \pm 0.01$ & $11 \pm 0.56$ & $13 \pm 0.16$ & $11 \pm 0.21$ & $11 \pm 0.31$ & $13 \pm 0.14$ \\
\hline $\begin{array}{c}\text { Staphylococcus } \\
\text { aureus }\end{array}$ & $13 \pm 0.27$ & $11 \pm 0.12$ & $14 \pm 0.08$ & $16 \pm 0.01$ & $10 \pm 0.53$ & $13 \pm 0.24$ & $13 \pm 0.13$ & $13 \pm 0.76$ & $11 \pm 0.03$ & $11 \pm 0.44$ & $14 \pm 0.15$ \\
\hline $\begin{array}{c}\text { Xanthomonasaxo } \\
\text { nopodis }\end{array}$ & $11 \pm 0.27$ & $10 \pm 0.12$ & $14 \pm 0.07$ & $14 \pm 0.28$ & $13 \pm 0.22$ & $15 \pm 0.01$ & $11 \pm 0.10$ & $14 \pm 0.25$ & $11 \pm 0.23$ & $10 \pm 0.08$ & $16 \pm 0.16$ \\
\hline
\end{tabular}




\section{Conclusion}

The current study was initiated because of the increasing resistance to antibiotics including bacteria. In Khyber Agency, 58 plants were collected in the current survey during 2015 to 2016. These medicinal plants are sold locally as well as internationally in markets and support the economy of the local peoples. Only 11 medicinal plants are currently trading in national and international markets, while the rest of the medicinal plants were used and sold locally. J. adhatoda, D. stramonium, B. procumbens, $C$. murale and E. helioscopia were selected for antimicrobial activity. The leaves and flowers extracts of each plant showed a significant effect against all the selected five different species of bacteria. The emergence of new infectious diseases, the resurgence of several infections that appeared to have been controlled and the increase in bacterial resistance have created the necessity for studies of more and more plants for their antimicrobial activity. In future these six medicinal species need to explore for the novel compounds, to play role in modern medicine against bacteria.

\section{Authors' contributions}

Conceived and designed the experiments: M Arif \& M Shuaib. Performed the experiments: K Ali, U Zeb \& Z Urooj, Analyzed the data: SQ Shah, $\mathrm{AB}$ Khan \& $\mathrm{F}$ Hussain. Contributed reagents/ materials/ analysis tools: S Hussain, SS Shah, S Ahmed T Aslam \& M Shah. Wrote the paper: M Shuaib, I Khan \& F Hussain.

\section{Acknowledgments}

The authors gratefully acknowledge the support received from AU Peshawar. This research work received no specific grant from any donor agency in the public, commercial, or not-for-profit sectors, and these organizations have had no involvement in the analysis and interpretation of data, in the writing of the draft, and in the decision to submit the article for publication. The authors have not declared any conflict of interests.

\section{References}

1. Ullah R, Hussain Z, Iqbal Z, Hussain J \& Khan FU (2010). Traditional uses of medicinal plants in Darra Adam Khel NWFP Pakistan. J Med Plan Res 4(17): 1815-1821.

2. Nasir E \& Ali SI (1971-1991). Flora of West Pakistan No1-190. Pakistan Agri Research Council, Islamabad.

3. Hamayun M, Khan SA, Iqbal I, Rehman $\mathrm{G}$ \& Hayat $\mathrm{T}$ (2005). Ethnobotanical profile of Utror and Gabral Valleys, District Swat, Pakistan. Eth. Leaflets. Vol. 2003(1).

4. Shuaib M, Khan I, Sharifullah, Khan R, Hashmatullah, Mubarik S \& Naz R (2014). Ethnobotanical studies of spring flora of Dir Lower, Khyber Pakhtunkhwa, Pakistan. Pak. J Weed Sci Res 20(1): 37-49.

5. Erdemgil FZ, Semra I, Ferhan K, Cigdem K, Ayse M, Mohammad A \& Shabir A (2007). Chemical composition and biological activity of the essential oil of Perovskia atriplicifolia from Pakistan. Pharmaceutical Biol 45: 324-331.

6. Butler MS (2004). The role of natural product chemistry in drug discovery. $J$ Nat Prod 67(12): 2141-2153.

7. Shuaib M, Ali K, Zeb U, Hussain F, Zeb MA, Hussain S \& Hussain F (2017). Evaluation of Pistacia integrrima; an important plant. Inter $J$ of Biosciences 11(5): 412-42.

8. Singh A (2007). Herbal medicine-dream unresolved. Pharmacognosy Reviews 2: 375.

9. Awadh A \& Ali NA (1997). Flora of West Pakistan, National Herbarium Agri Res Council, Rawalpindi 100: 65-83.

10. Carron EA, Maran JM, Montero L, Fernandozalgo A \& Dominguez A (1987). Antimicrobial properties of some extracts obtained from some Mediterranean plants of medicinal value. 
Plantes Medicinales et Phytotherapie 21: 195-202.

11. Shuaib M, Khan I, Sharifullah \& Khan MT (2015). Study of Medicinal Plants of Lower Dir, Timergara, Tehsil Balambat, Khyber Pakhtunkhwa-Pakistan. American-Eurasian J Agric Environ Sci 15(10): 2088-2094.

12. Sharifullah, Shuaib M, Khan I, Ali S, Ali K \& Kumar T (2016). Study of important medicinal plants of district Dir Upper, Pakistan. Pak J Weed Sci Res 22(4): 595606.

13. Sher H \& Hussain F (2009). Ethnobotanical evaluation of some plant resources in Northern part of Pakistan. Afr J. Biotechnol 8(17): 4066-4076.

14. Ali K, Shuaib M, Hussain Z, Sajjad W, Ali F \& Fazil M (2016). Ethnobotanical assessment of the medicinal flora of Khyber agency, Pakistan. Pak J Weed Sci Res 22(4): 607-616.

15. Hussain J, Khan AL, Rehman N, Hamayun M, Shah T, Nisar M, Bano T, Shinwari ZK \& Lee I (2009). Proximate and nutrient analysis of selected vegetable species: A case study of Karak region, Pakistan. Afr J Biotechnol 8(12): 2725-2729.

16. Khan AA \& Khan J (2011). Market Survey of Useful Plants in the Mountain Region of Abbottabad District, Pakistan. World Appl Sci J 14(4): 510-513.
17. Shinwari MI \& Khan MA (2000). Folk use of medicinal herbs of Margalla Hills National Park, Islamabad. $J$ of Ethnopharmacology 69: 45-56.

18. Shuaib M, Jang N, Ayub S, Rahman SU, Khan MT, Fazil M \& Ali Z (2016). Export of Important Medicinal Plants to Local and International Market from District Dir, Khyber Pakhtunkhwa, Pakistan. American-Eurasian J Agric \& EnvironSci 16(1): 99-103.

19. Silver LL \& Bostian KA (1993). Discovery and development of new antibiotics: the problem of antibiotic resistance. Antimicrobial Agents Chemother 37: 377-383.

20. Chang ST, Wu JH, Wang SY, Kang PL, Yang NS \& Yur L F (2001). J Agri Food Chem 49: 3420-3424.

21. Ali S, Ali K, Hussain Z, Khan MS, Khan WM, Wali S \& Shuaib M (2016). Phytochemical screening and antimicrobial activity of selected medicinal plant species. Pure and Appl Biol 6(2): 418-425.

22. Ali K, Shuaib M, Ilyas M, Hussain F \& Hussain F(2017). Medicinal Uses of Chemical Extracts from Withania somnifera and Its Antimicrobial Activity: A Mini-Review. PSM Microbiol 2(1): 20-23. 